\title{
Effect of fly and bottom ash mixture from combustion of biomass on strength of cement mortar
}

\author{
Matgorzata Ulewicz ${ }^{1, *}$, and Jakub Jura ${ }^{1}$ \\ ${ }^{1}$ Facutly of Civil Engineering, Czestochowa University of Technology, 42-201 Czestochowa, Poland
}

\begin{abstract}
The preliminary results of fly and bottom ash mixture form combustion od biomass ( $80 \%$ of tree waste and $20 \%$ of palm kernel shells) for the produce of ceramic mortars has been presented. Currently, bioash from fluidized bed are deposited in landfills. Use of this ash to production of cement mortar instead of sand will reduce the consumption of the mineral resources. The chemical composition of this waste materials was determined using X-ray fluorescence (spectrometer ARL Advant 'XP). Cement mortar were made using CEM I $42.5 \mathrm{R}$. The ash were added in an amount $20 \%$ of cement weight (in different proportions of fly and bottom ash). The results showed, that the compressive strength (after 28 days) of cement mortar containing ash is higher regardless of the type of ash mixture used. The highest compressive strength (increased by $7.0 \%$ compared to the control sample) was found for cement mortars in which the ratio of fly ash to bottom ash was 10/90. This mortars also showed the highest frost resistance (after 150 cycles freezes and unfreeze). The largest decrease the compressive strength (over 18.7\%) after the frost resistance test. While cement mortars in which the ratio of fly ash to bottom ash was $90 / 10$ showed the highest frost resistance (after 150 cycles freezes and unfreeze).
\end{abstract}

\section{Introduction}

The replacement of traditional raw material in building materials by fly ash and bottom ash coming from cocombusion of biomass leads to relevant environmental benefits. It avoids the extraction of large quantities of raw materials from the earth, reduces energy costs and also prevents landfill problems. Unfortunately in recent years, the energy is produced increasingly from only biomass [ 1 , 2]. The use of biomass for energy production presents several economical and environmental advantages. Biomass is a renewable fuel meaning that it can be used to reduce the emissions associated with the greenhouse effect, while it also reduces the need to import fossil fuels such as coal, oil and natural gas. However, the fly ash generated by combustion of biomass in fluidized bed differ substantially their physicochemical and morphological properties from a traditional ash produced during combustion of coals [3-8] as well as cocombustion of biomass [9-11]. The quantity and quality of ashes produced in electrical plant during combustion of biomass are strongly influenced by the characteristics of the biomass used, such as: agriculture wastes, seed, wood or bark $[12,13]$. Therefore, it is important to determine the characteristics of the fly ash and bottom ash produced by the combustion of biomass, because organic and mineralogical composition of the waste and its grain size determine the possibilities of their economic use or utilization.

Several studies proposed that fly ash, from cocombustion of coal and biomass, can be used as a soil ameliorate that may improve physical, chemical and biological properties of the degraded soils and is a source of readily available plant micro-and macro-nutrients $[14,15]$. Several authors reported on the use of fly ash, from co-combustion of biomass, in various civil engineering applications such as construction of highways [16-18], ceramic production [19, 20], concrete and concrete like bricks, blocks and paving stones [21-23], and asphalt concrete [24].

The possibility of replacement natural fine aggregate by industrial by-products such as fly ash offers technical, economic and environmental advantages which are of great importance in the present context of sustainability in the construction sector. Unfortunately, the replacement of natural minerals by fly ashes, from co-combustion of biomass, is not easy due to the different characteristics of these materials. Agro-waste ashes, containing a large amount of silica in amorphous form, have potential for use as pozzolanic materials replacing cement. The ash from co-combustion of coal and biomass such as herbaceous, pure wood, and rice husk can be used for the production of concrete [23, 25, 26]. Unfortunately, so far there are no reports on the possibility of the use of fly ash from the combustion only of biomass to production of building materials. Typically, fly ash from biomass combustion contains more alkali metals as sodium and potassium $\left(\mathrm{Na}_{2} \mathrm{O}, \mathrm{K}_{2} \mathrm{O}\right)$ and less alumina $\left(\mathrm{Al}_{2} \mathrm{O}_{3}\right)$ than coal fly ash, traditionally used as a pozzolanic additive in cement formulations. Although many researchers have shown potential applications of fly ash from co-combustion of biomass as building and construction materials, further

\footnotetext{
* Corresponding author: ulewicz@bud.pcz.czest.pl
} 
investigations should be carried out, especially for the ashes from combustion of biomass.

\section{Experimental}

To the study were used fly and bottom ash formed during the combustion of biomass in power plant from province of Swietokrzyskie. The burned biomass in a fluidized bed: $80 \%$ of tree waste and $20 \%$ of palm kernel shells. The chemical composition (Table 1) of the material was determined by using X-ray fluorescence (ARL Advant'XP spectrometer). In research, the ash were added in an amount $20 \%$ of cement weight and were used in different proportions of fly (PL) and bottom (PD) ash. The composition of the tested mortars are shown in Table 2.

Table 1. Chemical composition fly and bottom ash, \%.

\begin{tabular}{|c|c|c|}
\hline Component & Fly ash & Bottom ash \\
\hline $\mathrm{SiO}_{2}$ & 57.45 & 89.02 \\
\hline $\mathrm{CaO}$ & 17.26 & 3.85 \\
\hline $\mathrm{Al}_{2} \mathrm{O}_{3}$ & 4.82 & 1.54 \\
\hline $\mathrm{MgO}$ & 2.32 & 0.58 \\
\hline $\mathrm{MnO}$ & 0.51 & 0.17 \\
\hline $\mathrm{Fe}_{2} \mathrm{O}_{3}$ & 2.94 & 1.03 \\
\hline $\mathrm{K}_{2} \mathrm{O}$ & 3.93 & 2.07 \\
\hline $\mathrm{Na}_{2} \mathrm{O}$ & 0.39 & 0.18 \\
\hline $\mathrm{P}_{2} \mathrm{O}_{5}$ & 2.01 & 0.36 \\
\hline $\mathrm{TiO}_{2}$ & 0.30 & 0.11 \\
\hline $\mathrm{SO}_{3}$ & 2.71 & 0.49 \\
\hline $\mathrm{Cl}$ & 1.06 & 0.58 \\
\hline $\mathrm{Other}$ & 4.30 & 0.02 \\
\hline
\end{tabular}

Table 2. Composition of the studied cement mortar.

\begin{tabular}{|c|c|c|c|c|c|}
\hline Components & M1* & M2 & M3 & M4 & M5 \\
\hline Cement, g & 450 & 450 & 450 & 450 & 450 \\
\hline Water, $\mathrm{cm}^{3}$ & 225 & 225 & 225 & 225 & 225 \\
\hline $\begin{array}{c}\text { Naturally } \\
\text { moulding sand, g }\end{array}$ & 1350 & 1260 & 1260 & 1260 & 1260 \\
\hline $\mathrm{W} / \mathrm{C}$ & 0.50 & 0.50 & 0.50 & 0.50 & 0.50 \\
\hline $\mathrm{PD} / \mathrm{PL}, \mathrm{g}$ & - & $81 / 9$ & $72 / 18$ & $9 / 81$ & $18 / 72$ \\
\hline PD/PL, $\%$ & - & $90 / 10$ & $80 / 20$ & $10 / 90$ & $20 / 80$ \\
\hline
\end{tabular}

Bars with the following dimensions: $4 \times 4 \times 16 \mathrm{~cm}$ were made in accordance with PN-EN196-1 standards. In the research was used municipal water from the intake of the city of Czestochowa with a pH of 7.7 and the content of nitrate and chloride ions equal to 34.3 and $30.9 \mathrm{mg} / \mathrm{dm}^{3}$. Electrical conductivity of water was $480 \mu \mathrm{S} / \mathrm{m}$. There was used Portland cement CEM I 42.5 R (Cemex). The watercement ratio (the ratio of the weight of water to the weight of cement used in a mix) in the cement mortars was equal 0.50 . Ceramic products after 24 hours were disassembled and placed in a water bath with temperature $20 \pm 1^{\circ} \mathrm{C}$, where they remained for 27 days. Obtained mortars were subjected to microscopic examination (LEO Electron Microscopy Ltd.) and there was identified their compressive strength (PN-EN-196-1) and absorbability
(PN-85/B-04500). For each test, three samples were made.

\section{Results and discussion}

In the first stage of research, the compressive strength of cement mortars was determined. As can be seen from Table 3, the compressive strength (after 28 days) of cement mortar containig fly and botttom ash mixture is higher compared to the control sample. Such a trend was observed regardless of the type of ash mixture used. The highest compressive strength (increased by $7.0 \%$ compared to the control sample) was found for cement mortars in which the percent ratio of fly ash to bottom ash was $10 / 90$. Whereas samples containing mixture PD/PL ash equal 80/20 exhibited comparable compressive strength with the control sample. While, cement mortars with addition of ash mixture PD/PL in percent ratio equal $10 / 90$ and 20/80 showed an increase in frost resistance about 5.7 and $15.2 \%$ compared with the control sample. For this cement mortar, the absorbability increase of 10.5 and $13.8 \%$ compared with the control sample was observed. Whereas, the cement mortar containing wastes $\mathrm{PD} / \mathrm{PL}$ in percent ratio equal $90 / 10$ and $80 / 20$ showed an increase compressive strength only about 1.6 and $4.7 \%$ compared with the control sample. This mortars showed the largest decrease the compressive strength (over 18\%) after the frost resistance test (after 150 cycles freezes and unfreeze).

Table 3. Properties of the studied cement mortar (the mean from three tests).

\begin{tabular}{|c|c|c|c|c|c|}
\hline Properties & M1* & M2 & M3 & M4 & M5 \\
\hline $\begin{array}{c}\text { Compressive strength, } \\
\text { MPa }\end{array}$ & 64.0 & 67.0 & 65.0 & 68.5 & 66.0 \\
\hline Absorbability, \% & 4.49 & 4.98 & 5.14 & 4.96 & 5.11 \\
\hline $\begin{array}{c}\text { Compressive strength } \\
\text { after testing frost } \\
\text { resistance, MPa }\end{array}$ & 52.5 & 54.5 & 52.5 & 60.5 & 55.5 \\
\hline
\end{tabular}

Microstructural studies of cement mortars (Fig. 1) showed their heterogeneous microstructure, particularly in the contact area of ash with cement grout. The addition of ash waste and low water-cement ratio (w/c) of 0.5 has caused creation of tight structure of cement mortar and consequently not only increase in mechanical properties of the cement mortars but also fit of absorbability of mortar and increase in frost resistance.

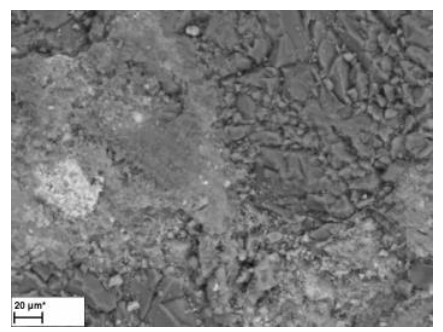

a) 


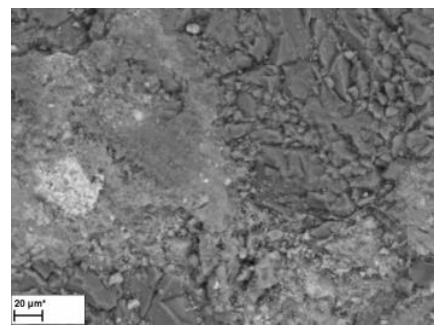

b)

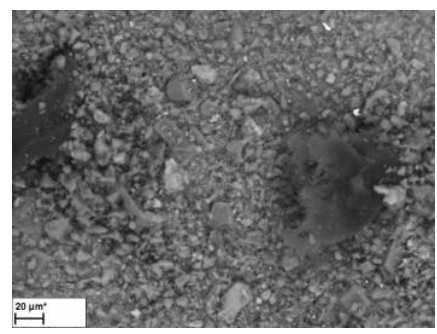

c)

Fig. 1. SEM micrographs of cement mortar M1* (a), M2 (b), and M4 (c).

\section{Conclusion}

Cement mortar is the most extensively used material for construction of different buildings. During the cement mortar production large amounts of natural sand is used. The replacement of the natural aggregates by fly and bottom ash mixture from combustion of biomass reduce consumption of raw materials and will have a good influence on the environment.

Based on experimental studies, we can conclude that it is possible to use fly and bottom ash mixture for production of cement mortar. Studies shown that, the compressive strength of cement mortar containing bio-ash increases is higher than control simples. The highest compressive strength (increased by $7.0 \%$ compared to the control sample) showed cement mortars containing the fly ash and bottom ash mixture in the percent ratio equal $90 / 10$. This mortar after 100 cycles freezing and defrosting showed strength loss of $11.7 \%$ compared to the control samples.

\section{References}

1. J.L Easterly, M. Durnham, Biomass Bioenergy, 10, 79-92 (1996)

2. R. Saidura, E.A. Abdelaziza, A. Demirbasb, M.S. Hossaina, S. Mekhilef, Renew. Sust. Energ. Rev., 15, 2262-2289 (2011)

3. D. Nordgren, H. Hedman, N. Padban, D. Boström, M. Öhman, Fuel Process. Technol., 105, 52-58 (2013)
4. K. Trybalski, W. Kępys, A. Krawczykowska, D. Krawczykowski, D. Szponder, Pol. J. Environ. Stud., 23, 1427-1431 (2014)

5. Y. Zheng, P.A. Jensen, A. D. Jensen, B. Sander, H. Junker, Fuel, 86, 1008-1020 (2007)

6. Y. Shao, J. Wang, F. Preto, J. Zhu, Ch. Xu, Energies, 5, 5171-5189 (2012)

7. R.P. Girón, B. Ruiz, E. Fuente, R.R. Gil, I. SuárezRuiz, Fuel, 114, 71-77 (2013)

8. S. V. Vassilev, D. Baxter, L.K. Andersen, Ch. G. Vassileva, Fuel, 105, 40-76 (2013)

9. Ch. J. Zygarlicke, B. C. Folkedahl, Prepr. Pap.-Am. Chem. Soc., Div. Fuel Chem., 48, 641-642 (2003)

10. A. Gaik, A. Ściubidło, Energetyka, 11, 834-839 (2013)

11. R. Rajamma, R.J. Ball, L.A.C. Tarelho, G. C. Allen, J.A. Labrinchad, V.M. Ferreira, J. Hazard. Mater., 172, 1049-1060 (2009)

12. A.A.T. Masiá, B.J.P. Buhre, R.P. Gupta, T.F. Wall, Fuel Process. Technol., 88, 1071-1081 (2007)

13. P. Kishor, A.K. Ghosh, D, Kumar, Asian J. Agr. Res., 4,1-14 (2010)

14. S. Aggarawal, G.R. Singh, B.R. Yadav, J. Agr. Physics, 9, 20-23 (2009)

15. C. Ferreira, A. Ribeiro, L. Ottosen, J. Hazard. Mater. B, 96, 201-216 (2003)

16. J.R. Kleven, T.B. Edil, C.H. Benson, Trans Res Rec. Washington DC: Transportation Research Board, 40$48(2000)$

18. T. Abichou, C.H. Benson, T.B. Edil, Geotechnical Special Publication ASCE, 79, 210-223 (1998)

19. E. S. Abdrakhimova, V. Z. Abdrakhimov, Solid Fuel Chemistry, 46, 185-190 (2012)

20. L. Pérez-Villarejo, D. Eliche-Quesada, Fco. J. Iglesias-Godino, C. Martínez-García, Fco. A. Corpas-Iglesias, J. Environ. Manag., 95, 349-354 (2012)

21. T.R. Naik, R.N. Kraus, Y. M. Chun, W.B. Ramme, R. Siddique, ACI Mater. J., 101, 99-206 (2004)

22. T.R. Naik, R.N. Kraus, Y. M. Chun, W.B. Ramme, S.S. Singh, J. Mater. Civil Eng., ASCE 15, 400-407 (2003)

24. J. M. Khatib, D.J. Ellis, ACI Spl. Pub SP-200, ACI, 733-48 (2001)

25. S. Fiore, M. C. Zanetti, Am. J. Environ. Sci., 3, 135142 (2007)

26. S. Javed, C.W. Lovell, L.E. Wood, Trans. Res. Board, 1437, 27-34 (1994)

27. H. Chao-Lung, B. L. Anh-Tuan, Ch. Chun-Tsun, Constr. Build. Mater., 25, 3768-3772 (2011)

28. N. Van Tuan, G. Ye, K. van Breugel, A. L.A. Fraaij, B. D. Dai, Constr. Build. Mater., 25, 2030-2035 (2011) 